\title{
Kuitumäärityksen merkitys kotieläinten ruokinnassa
}

\author{
MAIJA-LIISA SALO \\ Helsingin yliopiston kotieläintieteen laitos, 00710 Helsinki 71, Finland
}

\section{The significance of fibre analyses in animal nutrition}

Maija-Liisa Salo

Department of Animal Husbandry, University of Helsinki, 00710 Helsinki 71

\begin{abstract}
Information is given on the chemical composition and digestibility of cell-wall constituents. Special attention is paid to the value of different analytical systems in the prediction of digestibility and nutritive value of feeds.

As a part of the Weende analytical scheme, crude fibre is still of importance in feed tables. It is al used in farming practice as a rough quality criterion for forages and certain other feeds. In evaluating it.e digestibility of forages by an analytical system, however, the biological methods - especially in vitro a.a in sacco digestibilities - have proved superior to the Weende crude fibre and van Soest's fibre analyses and to other chemical methods. Certain combinations of chemical and biological methods also have been found useful. The same systems are not available for concentrates. Schemes have been developed for concentrates based on the contents of starch, sugar, protein and fat.
\end{abstract}

\section{Johdanto}

Kuidulla ymmärretään rehun vähäarvoista osaa, mutta termi ei ole yksiselitteinen. Sillä voidaan tarkoittaa soluseinämäaineiden kokonaismäärää, Weenden raakakuitua tai jotakin muuta kuidun osaryhmää. Tässä artikkelissa tarkastellaan aluksi kuitua rehun aine-osana, mutta pääaiheena on raakakuitu ja sen vaihtoehdoksi kehitetyt määritykset rehuarvon kriteetinä.

\section{Kasvirehujen tärkeimmät aineryhmät ja niiden hyväksikäyttö}

Kasviaineet voidaan jakaa kahdeksi pääryhmäksi: solunseinämä- eli struktuuri- eli kuituaineiksi ja sisällys- eli soluaineiksi. Edelliset ovat kasveille fysikaalisesti tärkeitä, koska ne muodostavat solukon ja kasvien tukirakenteen. Sisällysaineet vuorostaan vastaavat kasvifysiologiasta ja toimivat 
energianlähteenä ja -varastona. Struktuuriaineiden pääryhmät ovat selluloosa, hemiselluloosa, pektiini, kumi- ja lima-aineet sekä ligniini, sisällysaineiden sokerit, fruktosaanit, tärkkelys, proteiinit, lipidit ja kasvihapot. Struktuuriaineiden liukoisuudessa on suuria eroja: helppoliukoisin pektiiniaines liukenee jo kuumaan veteen, kun taas selluloosa vaatii $72 \%$ rikkihapon ja ligniini kestää vielä sitäkin. Toisaalta pääosa lingiinistä ja hemiselluloosasta liukenee jo varsin laimeaan alkaaliliuokseen, mitä vastaan selluloosa vuorostaan on hyvin kestävää.

Kahtiajako pääryhmiksi on osuva myös ravintoarvon kannalta, sillä aineiden hajoaminen imeytymiskelpoiseen muotoon tapahtuu kummassakin ryhmässä omalla periaatteellaan. Sisällysaineet hydrolysoituvat rakenneyksiköikseen ruoansulatusrauhasten erittämillä entsyymeillä ja ovat järjestään hyvin sulavia. Seinämäaineisiin ruoansulatusentsyymit eivät tehoa, mutta ruoansulatuskanavan mikrobien valmistamat käytteet hajottavat polysakkarideja eläimelle käyttökelpoiseen muotoon. Ligniiniin nekään eivät tehoa. Seinämien erilainen kemiallinen koostumus ja erityisesti erilainen fysikaalinen rakenne vaikuttaa oleellisesti rehun sulavuuteen.

Vaikka kuitu on rehuarvoa alentava tekijä, on tietty kuitumäärä silti välttämätön, koska ruoansulatuskoneisto vaatii rehuun myös sulamatonta massaa. Yksimahaisilla kuidun tarve on kuitenkin vähäinen. Esim. tavallisessa sianrehussa on Weenden raakakuitua 5-6 \% ja kuituainesta kaikkiaan 15-20 $\%$. Sulamatta jää noin $20 \%$ kuiva-aineesta. Lihasialle tämä kuitupitoisuus on sopiva ja sen lisääminen $-\mathrm{mm}$. rehuvalioon lisätty ruohojauho - huonontaa rehun hyötysuhdetta. Emakko sen sijaan vaatii kuitutäydennystä, koska se saa rehua kokoonsa nähden paljon lihasikaa vähemmän. Asia on sama kuin kevyttä työtä tekevällä ihmisellä, jonka myös täytyy huolehtia kuidun riittävästä saannista.

Märehtijän ruoansulatus vaatii runsasta kuitumäärää ja lisäksi rehun tiettyä fysikaalista rakennetta. Karkearehun ja väkirehun suhteen pitää naudalla olla noin 40:60 \% kumpaankin suuntaan, jotta pötsifermentaatio tapahtuisi normaalisti. Jos väkirehun osuus on liian suuri, fermentaatio kiihtyy liian vilkkaaksi, pötsin $\mathrm{pH}$ laskee ja sekä mikrobit että isäntäeläin kärsivät. Jos taas korsirehua on liiaksi, mikrobeilta puuttuu helppoliukoista energiaa ja karkearehun sekä proteiinin hyväksikäyttö alenee.

\section{Kuitu ja muut rehun sulavuuden kriteerit}

Suurimman kustannuserän kotieläintaloudessa muodostavat rehut. Rehuyhdistelmä pyritään sen vuoksi laatimaan sellaiseksi, että tuoteyksikköä kohti kuluu mahdollisimman vähän rehuyksiköitä. Lähtökohdaksi tarvitaan tieto rehujen ravintoarvosta. Rehutaulukosta nähdään keskitasorehujen rehuarvot, mutta käytettävä rehu ei aina edusta keskitasoa. Eli taulukon rehuarvoa pitäisi tarkentaa. Suuritöiset eläinkokeet eivät tule kysymykseen ja niinpä on pyritty kehittämään laboratoriomenetelmiä, joiden tulokset korreloisivat mahdollisimman hyvin eläinkokeilla määritettyyn sulavuuteen. Sulavuus kun määrää rehuarvoa jo varsin pitkälle. 
Sama menetelmä ei kuitenkaan sovi rehulle kuin rehulle eikä kehittelytyössä tähän pyritäkään. Märehtijäin rehut vaativat oman menetelmänsä, yksimahaisten omansa. Ja märehtijäin rehuistakin runsaskuituinen karkearehu vaatii eri menetelmän kuin niukkakuituinen väkirehu. Kehittelytyö onkin tiiviimmin keskittynyt karkearehuihin, koska karkearehu kehittyneessäkin karjataloudessa säilyy sekä ravitsemuksellisista että taloudellisista syistä nautakarjan ruokinnan pohjana.

\section{Märehtijän karkearehulle tarkoitetut kriteerit}

Raakakuitu

Weenden raakakuitumääritys oli alunperin tarkoitettu kuvaamaan rehun vähäarvoista kuituainesta. Sen vastapoolina oli ryhmä typettömät uuteaineet, minkä vuorostaan piti kuvata helppoliukoista ja arvokasta hiilihydraattiainesta. Pian kuitenkin selvisi, että kahtiajakoon käytetty analyysimenetelmä oli virheellinen. Uuteaineisiin joutui myös suuri osa hemiselluloosaryhmän polysakkarideista ja lisäksi pääosa ravintona arvottomasta ligniinistä.

Näistä puutteista huolimatta raakakuitumääritys on pitkälti toista sataa vuotta säilyttänyt paikkansa rehuanalyysissä ja sittemmin virallisissa rehutaulukoissa yhtenä rehuarvon laskuperusteena. Sillä näet on myös monia hyviä puolia: se on kansainvälisesti tunnettu ja myös sen rajoitukset tunnetaan. Raakakuitupitoisuudesta voidaan varsin hyvin päätellä esim. nurmirehujen kasvuastetta ja jyvien sekä rouheiden kuoripitoisuutta.

Rehun struktuuriainepitoisuuden kriteeriksi se on kuitenkin huono, koska raakakuidun osuus struktuuriaineista ei ole vakio, vaan rïppuvainen rehulajista ja nurmikasveilla lisäksi kasvuasteesta. Myös raakakuidun koostumus vaihtelee. Esimerkkinä tästä on entisestä tutkimuksestani (SALO 1965b) poimittu oheinen taulukko.

Rehun sulavuuden kriteeriksi raakakuitu on niinikään heikonlainen, koska kuituaineen sulavuuteen vaikuttaa soluseinämien koostumuksen lisäksi niiden fysikaalinen rakenne. Ajatelkaamme vain puuainesta, mitä märehtijä ei pysty sulattamaan edes hienona jauhona. Tietyillä rehuilla raakakuituprosentti johtaa sen vuoksi rehun yli- tai aliarviointiin. Esimerkkinä mainitsen kaksi rehuryhmää: huonolaatuiset nurmirehut ja käsitellyt oljet.

Rehuksi viljeltäville heinäkasveille on ominaista, että raakakuitupitoisuus ei kukkimisvaiheen jälkeen nouse, mutta sulavuus laskee jatkuvasti. Vanhalla kasvuasteella korjatun ja kuivatusvaiheessa sateen liottaman heinän sekä liikakäyneen säilörehun rehuarvosta raakakuitu antaa sen vuoksi liian hyvän kuvan.

Käsitellyn oljen kohdalla tilanne on päinvastainen. Lipeä- ja ammoniakkikäsittely ei näy kuituprosentissa, vaikka sulavuus paranisi 10-20 prosenttiyksikköä. Käsittely ei näet hajota selluloosaa eikä muutakaan kuituun joutuvaa ainesta, vaan ainoastaan särkee solukon rakennetta niin että entsyymit pääsevät siihen paremmin vaikuttamaan.

Sulavuuskokeet ovat vielä alue, mihin raakakuitu sopii huonosti, vaikka 
Taulukko 1. Raakakuitu verrattuna seinämäaineiden kokonaismäärään ja selluloosapitoisuuteen. Table 1. Crude fibre compared to the total cell-wall contents and cellulose.

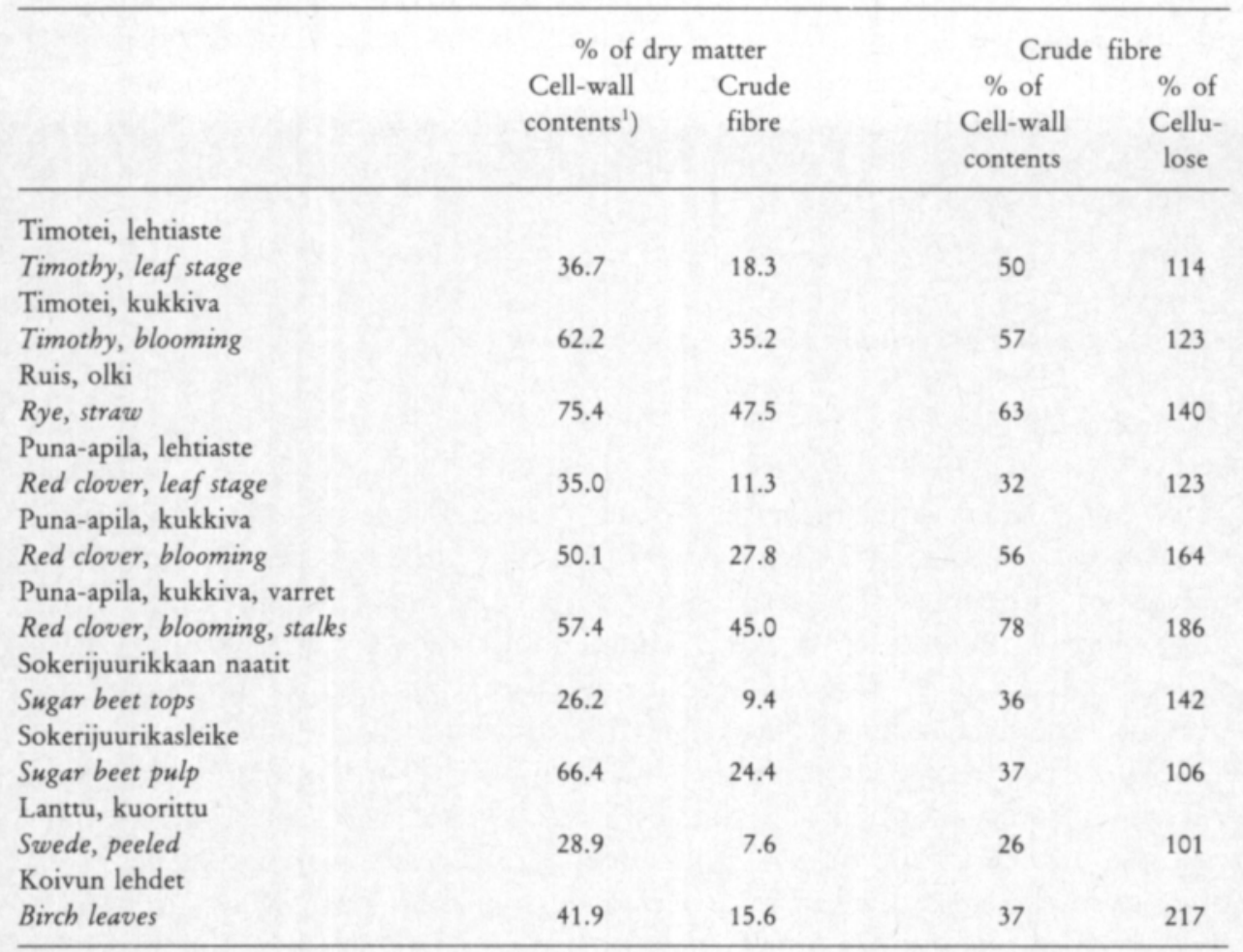

1) Hemiselluloosa + selluloosa + ligniini

Hemicellulose + cellulose + lignin (Method: SALO 1965 a)

se rehutaulukoissa laskuperusteena yleisesti esiintyykin. Se on sovinnaisella menetelmällä määritetty hydrolyysijäännös, eikä suinkaan kemialliseen koostumukseen perustuva yksikkö. Ruoansulatusprosessissa saattaa osa rehun raakakuidusta muuttua niin helppoliukoiseksi, että se sonnasta määritettynä joutuu typettömiin uuteaineisiin. Ei siis sula, vaan siirtyy ryhmästä toiseen. Kuidun sulavuus saadaan liian hyväksi, uuteaineiden liian huonoksi. Raakakuidun sulavuudessa esiintyykin hajontaa ja erityisen silmiinpistävää se on differenssinä määritetyillä rehuilla, joissa kaikki menetelmän epätarkkuudet kasaantuvat erotuksena lasketulle rehulle.

\section{Vaihtoehtoiset menetelmät}

Weenden raakakuidulle on kehitetty monia vaihtoehtoja ja tutkimustyö tällä alalla jatkuu. Ensimmäisinä kehitettiin kemiallisia menetelmiä, joilla kuitumäärityksen tapaan määritettiin liukenematon hydrolyysijäännös. Vanhemmista mainittakoon PALOHEIMOn ja PALOHEIMOn (1949) kettoainemääritys ja normaalikuitumenetelmä (GRIFFITH ja THOMAS 1955), jotka raakakuidun tapaan oli tarkoitettu kaikille rehuille.

Uudempia ja kansainvälisesti tunnettuja ovat karkearehuille tarkoitetut 
van SOESTin (1963 a, 1963 b, 1967) kuituryhmät NDF, ADF ja ADL, sekä niistä erotuksena laskettavat selluloosa ja hemiselluloosa. Keskeisenä reagenssina Soestin määrityksissä on detergenttiaine, mikä liuottaa tehokkaasti proteiineja ja lipidejä. Jäännökseksi jää solunseinämäainekompleksi, vähän epäpuhdas luonnollisesti. Teknisesti määritykset ovat hankalia, sillä erityisesti NDF-keitos kuohuu herkästi ja suodattuu huonosti. Näin mieto käsittely näet liuottaa monet aineet vain suspensioksi, mikä edellyttää hyvin karkeaa suodatinta. ADF-menetelmää on myöhemmin tarkennettu puhtaamman selluloosa-ligniinikompleksin saamiseksi lisäämällä määrityksen alkuun NDF-keitto (ROBBINS ym. 1975).

Selluloosa- ja hemiselluloosapitoisuus voidaan määrittää myös niiden kemialliseen koostumukseen perustuvina ryhminä (GAILLARD 1958, WAITE ja GORROD 1959, SALO 1965 a) ja hemiselluloosa lisäksi eri fraktioina. Ligniini tulee silloin määritetyksi happohydrolyysijäännöksenä. Botaanisesti tällaiset määritykset ovat mielenkiintoisia ja kuvaavat kukin tavallaan myös kasvin kuitupitoisuutta ja kuidun laatua. Rehun sulavuuteen selluloosa ja hemiselluloosa eivät korreloi, koska juuri niitä märehtijä pystyy varsin hyvin sulattamaan. Ligniini on rehun huonoimmin sulava komponentti ja korreloisi hyvinkin, jos se pystyttäisiin vähänkin tarkasti määrittämään. Tietty osa hemiselluloosaryhmästä - ksylaanit ja asetyylijohdannaiset erityisesti - on myös rehun huonosti sulavaa ainesta (MORRIS 1976).

Kemiallisten määritysten rinnalla on 1950-luvulta lähtien esiintynyt biologisia määrityksiä. Ensimmäiseksi kehitettiin pötsinesteen käyttöön perustuvia in vitro -sulavuusmäärityksiä, sitten kaupallisilla entsyymipreparaateilla suoritettavia menetelmiä ja viimeksi ns. in sacco -menetelmiä, missä inkubatio tapahtuu nylonpussissa eläimen pötsissä (KAUFMANN ym. 1978).

In vitro -menetelmät pyrkivät jäljittelemään ruoansulatusta pötsissä ja mahalaukussa. Ensimmäisessä vaiheessa pötsinesteen bakteerit sulattavat rehua, toisessa vaiheessa hydrolyysi jatkuu pepsiini- $\mathrm{HCl}$ :n avulla. Menetelmä juontaa alkunsa 1950-luvulta ja tunnetaan parhaiten sïnä muodossa, minkä TILLEY ja TERRY (1963) julkaisivat vuonna 1963. Siitä on olemassa lukuisia variaatioita, $\mathrm{mm}$. edellisestä vain teknisissä yksityiskohdissa poikkeava LAMPETERin menetelmä (1970), Ruotsissa käytössä oleva yksivaiheinen menetelmä (den BRAVER ja ERIKSSON 1967) sekä kaasuvolyymin mittaukseen perustuva MENKEn ym. (1979) menetelmä.

Sellulaasimenetelmät (JONES ja HAYWARD 1973) ovat teknisesti edellisiä helpompia, koska niissä käytetään pötsinesteen sijasta kaupallista entsyymipreparaattia. Sellulaasipreparaatti on nimestään huolimatta entsyymiseos, mutta silti paljon pötsinestettä vähätehoisempi. Pepsiinisellulaasimenetelmissä (GOTO ja MINSON 1977) hydrolyysiä on tehostettu lisäämällä alkuun pepsiinikäsittely, mutta tässäkin muodossa hydrolyysiteho on heikompi kuin in vitrossa.

Eräät tutkijat ovat liittäneet sellulaasi-inkubation edelle keiton $2 \mathrm{~N}$ $\mathrm{KOH}: s s a$, eräät toiset taas käyttävät yhdistelmää $2 \mathrm{~N} \mathrm{HCl}$ - sellulaasi pepsiini (KELLNER ja KIRCHGESSNER 1977). Näillä yhdistelmillä on päästy lähelle in vivo -tulosta, mutta menetelmät ovat vielä niin uusia, ettei niitä ole mukana julkaistuissa menetelmien vertailuissa. 
Uusimmista menetelmistä mainittakoon vielä infrapunatekniikkaan perustuva, jolla pyritään määrittämään myös rehun sulavuutta. Jos se saadaan kehitetyksi riittävään tarkkuuteen, saadaan siitä muita nopeampi rutiinimenetelmä.

In vitro -menetelmillä on tietyt heikkoutensa. Pahimpana pidetään pötsinesteen - ja samoin sellulaasipreparaatin - aktiivisuuden vaihteluita. Sarjaan täytyy sen vuoksi sisällyttää aina tietty märä standardinäytteitä, joiden mukaan koko sarjan tulos voidaan korjata normaalitasolle. Myös sokeat määritykset ovat välttämättömiä, koska pötsineste sisältää aina pieniä rehupartikkeleita. Riippuvuus fistelieläimestä on luonnollisesti myös heikko puoli.

\section{Menetelmien vertailu}

Menetelmien käyttökelpoisuuden kriteerinä on tulosten yhtäpitävyys in vivo -sulavuustulosten kanssa. Lähes 10 vuotta sitten keräämässäni aineistossa in vitro -menetelmä osoittautui muita selvästi paremmaksi, vaikka vitro-ryhmässä oli mukana monia menetelmävariaatioita. Kemiallisista paras oli ligniini, jota myös oli määritetty monilla menetelmillä. Raakakuitu, ADF ja normaalihappokuitu olivat niitä heikompia.

Äskettäin ovat saksalaiset MIKA ym. (1981) julkaisseet eri menetelmien vertailun. Edellä mainittujen menetelmien lisäksi mukana on ollut uudet nylonpussi-, pepsiini-sellulaasi, Menken kaasuvolyymi- ja van Soest'in korjatut menetelmät. Aineistona tutkijoilla oli 22 eri kasvuasteen ja korjuumenetelmän heinäkasvinäytettä, 4 mailasnäytettä ja 18 maissinäytettä, joista osa jyvineen. Tulokset he laskivat sekä koko aineistolle että erikseen heinäkasvi-mailasnäytteille ja maissille.

Koko aineistolle laskettu tulos osoitti, että parhaiten in vivo -tulosta selittivät biologiset menetelmät, joissa näyte fermentoitiin pötsissä (nylonpussi) tai kaksivaiheista menetelmää käyttäen keoputkessa $\left(r^{2}=0.81-0.93\right)$. Käymiskaasuvolyymin mittaaminen Menken mukaan oli näitä epätarkempi $\left(r^{2}=0.52\right)$ ja samaa luokkaa kuin pepsiini-sellulaasi -liukoisuus ja van Soest'in järjestelmän ligniini $\left(r^{2}=0.55-0.58\right)$. Ligniini oli siis tässäkin vertailussa kemiallisista paras, mutta selvästi biologisia heikompi. Raakakuitu, Soest'in kuituryhmät ja selluloosa olivat edellisiä heikompia $\left(\mathrm{r}^{2}\right.$ $=0.31-0.49)$ ja Soest'in korjatut menetelmät alkuperäisiä heikompia. Regression laskeminen useamman kemiallisen määrityksen pohjalla antoi yhtä menetelmää paremman, mutta silti biologisia menetelmiä heikomman tuloksen.

Kun aineisto jaettiin kahdeksi alaryhmäksi, olivat selitysasteet vähän toisenlaisia. Ryhmälle ruohot-mailanen saatiin in vitro- ja nylonpussimenetelmillä erittäin hyvä tulos ja kemiallisilla niitä paljon heikompi. Maissiryhmä suhtautui vähän toisin. Maissiaineisto oli sikäli heterogeeninen, että osa näytteistä sisälsi tärkkelystä, osa ei. Tärkkelys jää esim. pepsiinisellulaasimenetelmässä sulamatta, mistä seuraa ko. menetelmän erittäin huono ennustearvo. Monet muutkin menetelmät sopivat heikonlaisesti tuot- 
teille, jotka sisältävät tärkkelystä. Ne on tarkoitettu korsirehuille ja tähkineen korjattu maissi on jo puoliksi väkirehua.

Vertailututkimus osoitti biologiset menetelmät kemiallisia kiistattomasti paremmiksi. Tulos johtuu yksinkertaisesti siitä, että rehun hajoaminen perustuu biologisissa menetelmissä fermentaatioon, kuten vertailukohteessa eli in vivo -sulavuudessa. Kemialliset menetelmät ovat keinotekoisempia ja siksi myös tehottomampia. Parhaita niistä ovat ne, joilla märitetään heikosti sulava kuituryhmä, eli ligniini, ADF ja jopa raakakuitu. Selluloosa, hemiselluloosa ja NDF sopivat tarkoitukseen huonosti, koska ne sisältävät juuri parhaiten sulavaa kuitua.

Botaanisesti homogeenisella materiaalilla tehtävä on helpompi kuin heterogeenisella. Esimerkin kemiallisen märityksen heikkoudesta botaanisesti heterogeenisessa materiaalissa tarjoaa Mika ym:n tutkimuksen raakakuitu, minkä selitysaste eri ryhmillä oli seuraava:

\begin{tabular}{llll}
\hline & $\mathrm{n}$ & $\mathrm{r}^{2}$ & \\
\hline Maissiryhmä & 18 & 0.80 & eli tyydyttävä \\
Heinäkasvit + mailanen & 26 & 0.68 & eli välttävä \\
Kaikki yhdessä & 44 & 0.31 & eli heikko \\
\hline
\end{tabular}

Lisäkommenttina sanottakoon, että maissiryhmän muutamien näytteiden tärkkelys ei kuitumäärityksessä huononna tulosta, niinkuin se eräissä muissa määrityksissä tekee. Toisaalta tutkijat olivat yhdistäneet ryhmäksi kahden eri heimon näytteet, heinä- ja palkokasvit. Kummallekin erikseen olisi todennäköisesti saatu paremmat selitysasteet, niin erilaisia koostumukseltaan nämä kaksi nurmikasvilajia ovat.

\section{Kuitumä̈rityksen merkitys sian ja kanan rehuissa}

Sika ja kana ovat väkevän rehun syöjiä. Umpi- ja paksusuolessa tapahtuvan fermentaation ansiosta ne pystyvät kuitenkin sulattamaan pienen osan rehun seinämäainetta, lähinnä helppoliukoista pektiiniä. Se imeytyy haihtuvina rasvahappoina kuten märehtijällä, mutta sika - yleensä yksimahaiset - käyttävät sulaneen pektiinin hyväkseen paljon huonommalla hyötysuhteella kuin märehtijä (GÄDEKEN 1967, ALBERS \& HENKEL 1979). Paksusuolessa haihtuviksi hapoiksi fermentoituvalla aineella näyttää siten olevan varsin vähäinen ravintoarvo.

Ruoansulatusprosessiin vaadittavan kuitumäärän lihasika ja kana saa täysviljan ja rouheiden kuoriosista. Kuitulisäys vain huonontaa rehun hyötysuhdetta. Sen vuoksi esim. säilörehun antaminen lihasialle ei ole taloudellisesti kannattavaa. Emakko on asia erikseen. Tiineysaikana se tarvitsee niin vähän ravintoa, että pieni kuitutäydennys huonosti sulavan rehun muodossa on tarpeen.

Koska kuitu märehtijälläkin on lähinnä karkearehun rehuarvon para- 
metri, sillä ei sian rehun arvon mittana ole mainittavaa merkitystä. Sianrehulle - yleensäkään väkirehulle - ei liioin ole kehitetty in vitro -menetelmää vastaavaa sulavuuden mittaria. Jos rehuarvo halutaan märittää analyysitietä, ei hyvin sulavista rehuista ole järkevää määrittää sulamatonta osaa, vaan tärkeimmät ravintoaineet. Sian ja siipikarjan rehun energia-arvon laskemiseen onkin laadittu kaavoja, jotka perustuvat rehun tärkkelys-, sokeri-, proteiinija rasvapitoisuuteen. Vastaavia on myös märehtijän väkirehulle (WEINREICH 1980). Jo yksin tärkkelyspitoisuus kertoo viljan rehuarvosta enemmän kuin raakakuitu (SALO 1978).

Raakakuitu antaa silti karkean arvion tavallisista sian rehuista kuten viljasta ja rouheista, joissa kuitumäärityksen rajoitukset tunnetaan. Lesevaltaisten viljan sivutuotteiden - vehnänleseen, mäskin ja rankin - arvosta sianrehuna kuituprosentti antaa vähän liian hyvän kuvan, koska kuitukeitot hajottavat viljan pentosaanivaltaista siemenkuorta tehokkaammin kuin sian ruoansulatus. Rehuhiivakaan ei ole niin hyvää sianrehua kuin sen prosentin luokkaa oleva kuitupitoisuus antaa aiheen uskoa.

Sulavuuskokeisiin raakakuitu sopii sialla vielä märehtijää huonommin kananrehun sulavuuden määrityksissä sitä ei enää käytetäkään. Viljan kuidun sulavuudeksi saadaan tosin oikea arvo eli lähes nolla, koska valkuaisrehuna on kurrijauhe tai muu kuiduton animaalinen rehu. Kasviöljyrouheiden kuiduille rehutaulukoissa sen sijaan ilmoitetaan epäilyttävän korkeita sulavuusprosentteja, jopa korkeampia kuin märehtijäin taulukossa. Epäloogisen sulavuustiedon selitys lienee siinä, että kokeessa on perusrehuna ollut ohra, joka sisältää sulavaa kuitua hyvin vähän, ja metodiset ja muut virheet ovat tulleet rouheen osalle. Sianrehujen rehuarvon määrityksessä olisikin syytä luopua kuitumäärityksestä ja laskea erotuksena uuteaineiden sijasta kuidun ja uuteaineiden summa. Tai jos kuitumääritys välttämättä halutaan säilyttää, differenssikokeissa pitäisi kuitupitoisen valkuaisrehun rinnalla olla viljan tärkkelys eikä ohra.

\section{Päätelmät}

Loppupäätelmänä sanottakoon, että raakakuitumäärityksellä on yhä tietty arvonsa rehuopissa. Se kuuluu osana Weenden analyysijärjestelmään, mikä jatkuvasti on virallisena rehuarvon laskuperustana eri maissa. Vertaamalla tutkittavan rehun kuitupitoisuutta taulukon mallirehuun, voidaan päätellä onko rehu normaalitasoa vaiko sitä parempaa tai huonompaa ja karkeasti arvioida sen rehuarvoa. Jos kuitenkin halutaan laboratoriokeinoin määrittää tietyille karkearehuille tai viljaerille mahdollisimman tarkka rehuarvo, käytettävissä on raakakuitua parempia menetelmiä, jotka lisäksi saattavat olla kuitua helpompia suorittaa. 


\section{Kirjallisuusluettelo}

ALBERS, N. \& HENKEL, H. 1979. Untersuchungen über den Futterwert von pflanzlichen Zellwandbestandteilen beim Schwein. 1. Mitteilung: Der Einfluss von Pektinzulagen auf den Energieansatz. Z. Tierphysiol., Tierernähr. Futtermittelk. 42: 101-112.

BRAVER, E. J. den \& ERIKSSON, S. 1967. Determination of energy in grass hay by in vitro methods. Landbr.högsk. Ann. 33: 751-765.

GAILLARD, B. 1952. A detailed summative analysis of crude fibre and nitrogen-free extractives fractions of roughages. J. Sci. Food Agric. 9: 170-177.

GOTO, I. \& MINSON, D. J. 1977. Prediction of the dry matter digestibility of tropical grasses using a pepsin cellulase assay. Anim. Feed Sci. Technol. 2: 247-253.

GRIFFITH, G. ap. THOMAS, D. C. 1955. The use of normal-acid fibre and A.O.A.C. fibre determinations for the estimation of herbage digestibility. Agric. Progr. 30: 124-128.

GÄDEKEN, D. 1967. Untersuchungen über den energetischen Nährwert der Pektinstoffe bei monogastrischen Tieren. Diss. Universität zu Kiel, 94 p.

JONES, D. I. H. \& HAYWARD, M. V. 1973. A cellulase digestion technique for predicting the dry matter digestibility of grasses. J. Sci. Food Agric. 24: 1419-1426.

KAUFMANN,W., SINNER, M. \& DIETRICHS, H. H. 1978. Zur Verdaulichkeit von Stroh und Holz nach Aufschluss mit gesättigtem Wasserdampf bei höheren Temperaturen sowie Extraktion mit Wasser und verdünnter Natronlauge. Z. Tierphysiol. Tierernähr., Futtermittelk. 40: 91-96.

KELLNER, R. J. \& KIRCHGESSNER, M. 1977. Estimation of forage digestibility by a cellulase method. Z. Tierphysiol., Tierernähr. Futtermittelk. 39: 9-16.

LAMPETER, W. 1970. Eine neue Methode zur serienmässigen Untersuchung der Verdaulichkeit in vitro mittels "künstliches Pansens". Internat. Z. Landwirtsch. 6/1970: 664-668.

MENKE, K. H., RAAB, L., SALEWSKI, A., STEINGASS, H. \& FRITZ, D. 1979. Die Bestimmung des Gehaltes an Stärkeeinheiten und umsetzbarer Energie in Hohenheimer Futterwerttest (HFT). Der Tierzüchter 31: 20-28.

MIKA, V., PAUL, C., ZIMMER, E. \& KAUFMANN, W. 1981. Ein Vergleich verschiedener Labormethoden zur Schätzung der Verdaulichkeit von Grundfutter. Z. Tierphysiol., Tierernähr. Futtermittelk. 45: 132-141.

MORRIS, E. J. 1976. Acetyl content and sugar composition as factors influencing the digestion of grass cell walls in the rumen. Thesis, Aberdeen University, 102 p.

PALOHEIMO, L. \& PALOHEIMO, I. 1949. On the estimation of the total of vegetable membrane substances. J. Scient. Agric. Soc. Finl. 21: 1-16.

ROBBINS, C. T., SOEST, P. J. van, MAUTZ, W. W. \& MOEN, A. N. 1975. Feed analyses and digestion with reference to white-tailed deer. J. Wildl. Managem. 39: 67-79.

SALO, M.-L. 1965 a. Determination of carbohydrate fractions in animal foods and faeces. Acta Agr. Fenn. 105, 102 p.

SALO, M.-L. 1965 b. On the content of cell-wall constituents in various plant materials. J. Scient. Agric. Soc. Finl. 37: 127-134.

SALO, M.-L. 1978. Relationships between physical and chemical characteristics and calculated metabolizable energy values in barley and oats with highly variable volyme weights. J. Scient. Agric. Soc. Finl. 50: 276-284.

SOEST, P. J. van 1963 a. Use of detergents in the analysis of fibrous feeds. I. Preparation of fiber residues of low nitrogen content. J.A.O.A.C. 46: 825-829.

SOEST, P. J. van 1963 b. II. A rapid method for the determination of fiber and lignin. J.A.O.A.C. 46: 829-835.

SOEST, P. J. van 1967. Development of a comprehensive system of feed analyses and its application to forages. J. Anim. Sci. 26: 119-128.

TILLEY, J. M. A. \& TERRY, R. A. 1963. A two-stage technique for the in vitro digestion of forage crops. J. Br. Grassl. Soc. 18: 104-111.

WAITE, R. \& GORROD, A. R. N. 1959. The comprehensive analysis of grasses. J. Sci. Food Agric. 10: 317-326.

WEINREICH, O. 1980. Der Energiegehalt des Mischfutters: Ermittlung, Kennzeichnung, Kontrolle. Kraftfutter 9/1980: 420-424. 